\title{
Atypical Teratoid Rhabdoid Tumor in a Child: Case Report
}

\section{Tumor teratóide rabdóide atípico em uma criança: relato de caso}

\author{
Lucas Crociati Meguins ${ }^{1}$ Ronaldo Brasileiro de Miranda Batista Fernandes ${ }^{1}$ Adriana Giubilei Pimenta ${ }^{1}$ \\ Ricardo Lourenço Caramanti ${ }^{1}$ Eliane Milharcix Zanovelo ${ }^{2}$ Carmen Lúcia Penteado Lancellotti ${ }^{2}$ \\ Mário José Góes ${ }^{1}$
}

${ }^{1}$ Departamento de Ciências Neurológicas. Hospital de Base da Faculdade de Medicina de São José do Rio Preto (FAMERP), São José do Rio Preto, São Paulo, Brazil

2 Departamento de Patologia, Hospital de Base da Faculdade de Medicina de São José do Rio Preto (FAMERP), São José do Rio Preto, São Paulo, Brazil

\begin{abstract}
Address for correspondence Lucas Crociati Meguins, MD, Hospital de Base da Faculdade de Medicina de São José do Rio Preto (FAMERP), Rua Pedro Palotta, 101/31B. São José do Rio Preto, São Paulo, Brazil CEP 15092-205 (e-mail: lucascrociati@hotmail.com).
\end{abstract}

\begin{abstract}
Keywords

- atypical teratoid/ rhabdoid tumor

- childhood

- embryonal tumor

\section{Resumo}

Palavras-chave

- tumor teratoide rabdoide atípico (TTRA)

- criança

- tumor embrionário

Atypical teratoid/rhabdoid tumor (ATRT) is a rare and aggressive type of embryonal tumor of the central nervous system (CNS) occurring in childhood. The present study aims to describe the case of a 16-year-old girl who presented with an occipital mass lesion that was diagnosed as ATRT. We present a brief review of the current knowledge of the treatment of this rare neoplasm. A previously healthy 16 -year-old girl was referred after two episodes of partial complex seizure 2 weeks before admission. MRI showed a right parieto-occipital lesion with homogeneous contrast-enhancing and significant surrounding brain edema. The patient underwent uneventful surgical resection of the lesion and was discharged home on the fifth postoperative day. Pathologic examination revealed it to be ATRT. The patient was referred to chemotherapy and radiotherapy. After 6 months of follow-up, the patient remains free of seizure and disease progression. ATRT is a rare and aggressive disease. Therefore, early diagnosis and treatment may improve the patient's prognosis and quality of life.

O tumor teratoide rabdoide atípico (TTRA) é um tipo de neoplasia rara, com comportamento maligno, que atinge o sistema nervoso central (SNC) de crianças. O objetivo do presente estudo é relatar o caso de uma paciente de 16 anos de idade admitida no nosso serviço com uma lesão occipital que revelou tratar-se de TTRA em estudo anatomopatológico. Uma paciente previamente hígida foi admitida no nosso serviço referindo ocorrência de dois episódios de crises convulsivas nas últimas 2 semanas. A ressonância magnética de crânio mostrou a presença de lesão occipital direita com captação homogênea do meio de contraste. A paciente foi submetida a cirurgia de ressecção da lesão expansiva sem intercorrências. A análise histopatológica
\end{abstract}

received

February 4, 2015

accepted

June 12, 2015
DOI http://dx.doi.org/

10.1055/s-0035-1560034. ISSN 0103-5355.
Copyright $\odot 2015$ by Thieme Publicações License terms

Ltda, Rio de Janeiro, Brazil 
e imuno-histoquímica revelou tratar-se de TTRA. A paciente foi encaminhada para a realização de quimioterapia e radioterapia complementares ao tratamento cirúrgico. Após 6 meses de seguimento ambulatorial, a paciente encontra-se assintomática, sem recorrência das crises convulsivas e/ou progressão radiológica da doença. TTRA é uma doença rara e agressiva. Com isso, diagnóstico e tratamento antecipados podem aprimorar prognóstico e qualidade de vida dos pacientes.

\section{Introduction}

Atypical teratoid/rhabdoid tumor (ATRT) is a rare and aggressive type of embryonal tumor of the central nervous system (CNS) occurring in childhood. ${ }^{1-3}$ The incidence of all embryonal tumors in the United States is $0.66 / 100,000$ in persons 0 to 19 years old. ${ }^{4}$ ATRT commonly affects infants and young children, especially children younger than 3 years, and prognosis is generally poor. ${ }^{5}$ There is no standard treatment regimen for these tumors. Complete surgical resection is usually a challenge due to tumor location in the brain and young age at diagnosis. Additionally, radiation is often avoided in very young children due to severe neurocognitive late effects. ${ }^{6}$ Intensive chemotherapy regimens are currently under study, and no standard chemotherapy regimen exists for these patients. ${ }^{7}$

This study aims to describe the case of a 16-year-old girl who presented with an occipital mass lesion that was diagnosed as ATRT. We present a brief review of the current knowledge of the treatment of this rare neoplasm.

\section{Case Report}

A previously healthy 16 -year-old girl was referred after two episodes of partial complex seizure 2 weeks before admission. Magnetic resonance imaging (MRI) showed a right parieto-occipital lesion with homogeneous contrast-enhanc-

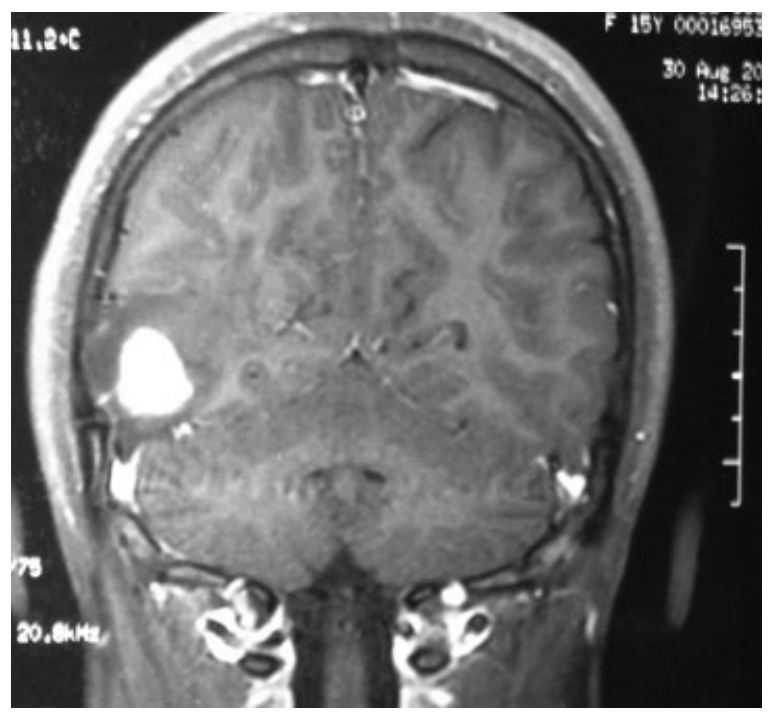

Fig. 1 MRI showing contrast enhancing right parieto-occipital nodular lesion. ing (-Fig. 1) and significant surrounding brain edema. The patient underwent uneventful surgical resection of the lesion and was discharged home on the fifth postoperative day. Microscopically, a tumor containing primitive neuroectodermal and rhabdoid cells was detected (-Fig. 2). The rhabdoid component was composed of medium-sized, round to oval cells with eccentric nuclei, prominent nucleoli, and eosinophilic cytoplasm. Immunohistologically, the rhabdoid cells were immunoreactive with smooth muscle actin (SMA), epithelial membrane antigen (EMA), and vimentin, but negative with desmin. The small cell embryonal component expressed vimentin. Ki67 was detected to be $15 \%$. The morphologic features were compatible with diagnosis of ATRT (-Fig. 3). The patient was referred to chemotherapy and radiotherapy. After 6 months of follow-up, the patient remains free of seizure and disease progression.

This case report was analyzed and approved by the Ethical Committee of our institution.

\section{Discussion}

ATRT was first described as a distinct of CNS rhabdoid tumor in 1987 and was further described in $1996 .^{8}$ The updated World Health Organization (WHO) classification of CNS tumors in 2000 included ATRT for the first time. ${ }^{9}$ ATRT belongs to a wider group of malignant rhabdoid tumors, which also include rhabdoid tumors of the kidney and extrarenal rhabdoid, which may develop in the lung, liver, and soft tissues. ${ }^{10,11}$ Common features of malignant rhabdoid tumors are inactivation of INI1 (also called hSNF5/INI1/ SMARCB1/BAF47) gene located in the chromosome $22 q 11.2,{ }^{12}$ presence of rhabdoid cells, and unique immunohistochemistry results such as presence of vimentin, epithelial membrane antigen, smooth muscle actin, and glial fibrillary. $^{13}$

The definitive diagnosis of ATRT relies on pathologic examination. However, clinical features of intracranial hypertension and some radiologic characteristics may help establish an adequate diagnosis. Although any part of the CNS may be involved, ATRT is mainly found in the posterior fossa. $8,14,15$ The left hemisphere is more prominently affected in older children and adults, and tumors may be located within or extending into the ventricles. ${ }^{16-18}$ Imaging features usually reveal large lesions, with precontrast computed tomography (CT) of an iso- or slightly hyperdense mass in relation to gray matter, with associated parenchymal edema calcification and hemorrhage. ${ }^{17-19}$ MRI findings usually show mixed signal intensity on T1- and T2-weighted images because of extensive 


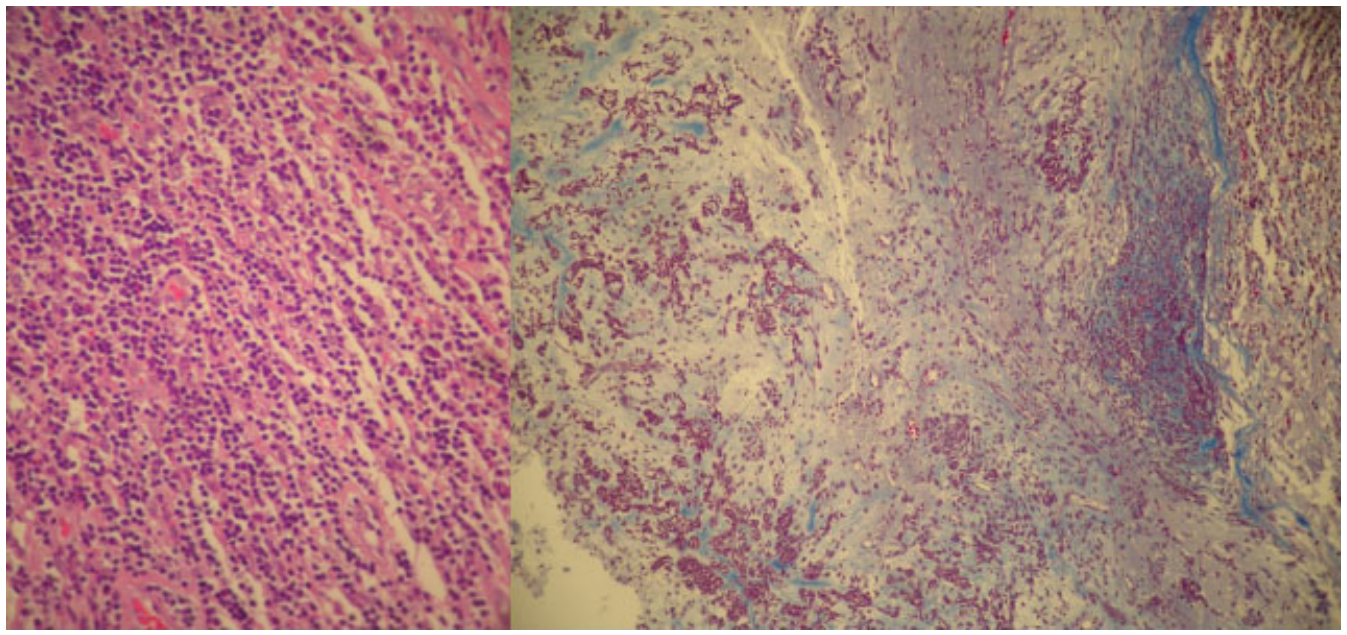

Fig. 2 Microscopic aspect of the tumor with rhabdoid eosinophilic cells and PNET-like cells.

EMA

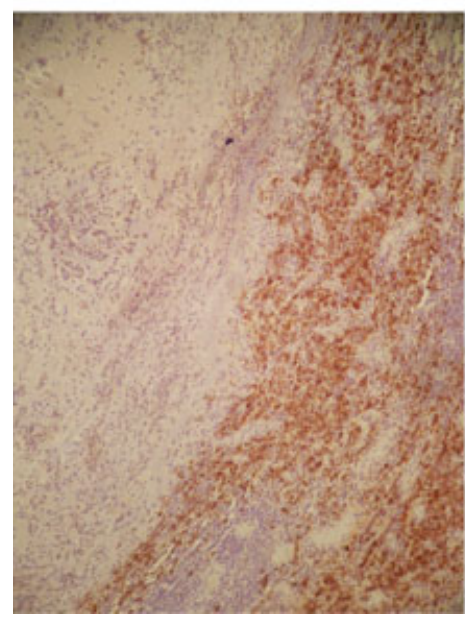

VIM

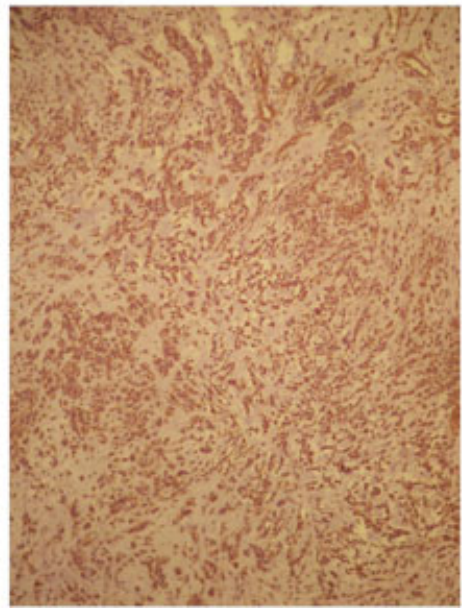

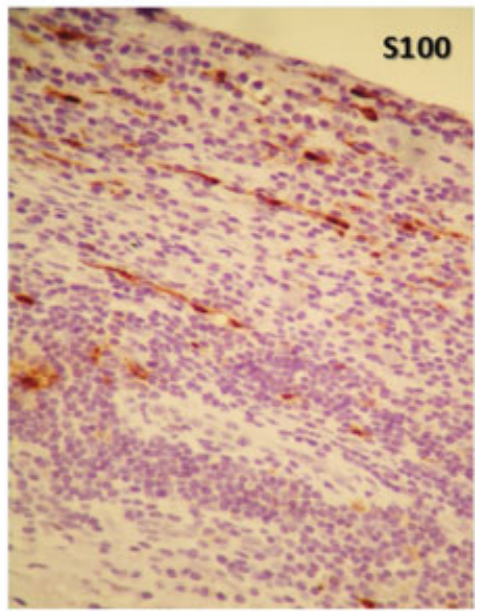

Fig. 3 Immunohistochemical study confirmed the characteristics of ATRT. Abbreviations: ATRT, atypical teratoid/rhabdoid tumor; EMA, epithelial membrane antigen.

necrosis and intratumoral hemorrhage. ${ }^{17,20}$ The solid component of the tumor is hypo- or isointense on T1weighted images and iso- or hyperintense on T2-weighted images compared with gray matter and is also well enhanced on postcontrast CT and MRI. ${ }^{17-19,21}$

Surgical treatment of ATRT has been proved as a favorable prognostic factor depending on the extension of resection. Gross total resection expanded median survival from 15 months (partial resection/biopsy) to 20 months. ${ }^{5}$ Chemotherapy and radiotherapy also demonstrated favorable survival outcome in patients with ATRT; however, these therapies have been used with limitation due to the adverse effects and high risk of neurocognitive impairment in patients younger than 3 years. ${ }^{5,12}$ In the present study, the patient was submitted to partial resection followed with radio- and chemotherapy. Our patient remains free of disease progression 6 months after surgery.

\section{Conclusion}

In conclusion, the present case highlights that ATRT is a rare and aggressive disease. Therefore, early diagnosis and treatment may improve the patient's prognosis and quality of life.

\section{Consent Statement}

Written informed consent was obtained from the patient for publication of this case report and any accompanying images. A copy of the written consent is available for review by the editor of this journal.

Conflict of Interest

The authors declare that they have no competing interests. 


\section{References}

1 Güner G, Önder S, Söylemezoğlu F. Cytomorphological features of atypical teratoid/rhabdoid tumor: an account of 12 years' experience. Diagn Cytopathol 2014;42(10):856-862

2 Souki C, Abdel-Rhaman M, Qasem A, Al-Hussaini M. Atypical teratoid rhabdoid tumor in adulthood. Clin Neuropathol 2014; 33(3):245-250

3 Al-Hussaini M, Dissi N, Al-Jumaily U, Swaidan M. Atypical teratoid rhabdoid tumor in childhood, 15 cases of a single institute experience. Turk Patoloji Derg 2014;30(1):43-54

4 Ostrom QT, Gittleman H, Farah P, et al. CBTRUS statistical report: primary brain and central nervous system tumors diagnosed in the United States in 2006-2010. Neuro-oncol 2013;15(Suppl 2): ii1-ii56

5 Hilden JM, Meerbaum S, Burger P, et al. Central nervous system atypical teratoid/rhabdoid tumor: results of therapy in children enrolled in a registry. J Clin Oncol 2004;22(14):2877-2884

6 Spiegler BJ, Kennedy K, Maze R, et al. Comparison of long-term neurocognitive outcomes in young children with acute lymphoblastic leukemia treated with cranial radiation or high-dose or very high-dose intravenous methotrexate. J Clin Oncol 2006;24(24):3858-3864

7 Ostrom QT, Chen Y, M de Blank P, et al. The descriptive epidemiology of atypical teratoid/rhabdoid tumors in the United States, 2001-2010. Neuro-oncol 2014;16(10):1392-1399

8 Rorke LB, Packer RJ, Biegel JA. Central nervous system atypical teratoid/rhabdoid tumors of infancy and childhood: definition of an entity. J Neurosurg 1996;85(1):56-65

9 Kleihues P, Cavenee W. Tumours of the Nervous System: World Health Organization Classification of Tumours. Lyon, France: IARC Press; 2000

10 Wick MR, Ritter JH, Dehner LP. Malignant rhabdoid tumors: a clinicopathologic review and conceptual discussion. Semin Diagn Pathol 1995;12(3):233-248
11 Lee HY, Yoon CS, Sevenet N, Rajalingam V, Delattre O, Walford NQ. Rhabdoid tumor of the kidney is a component of the rhabdoid predisposition syndrome. Pediatr Dev Pathol 2002;5(4):395-399

12 Caeiro C, Augusto I, Jaraquemada T, Sarmento C, Damasceno M. Tumor teratóide rabdóide atípico num adulto. Caso clínico e revisão da literatura. Arquivos de Medicina 2008;22(6):165-167

13 Bhattacharjee M, Hicks J, Langford L, et al. Central nervous system atypical teratoid/rhabdoid tumors of infancy and childhood. Ultrastruct Pathol 1997;21(4):369-378

14 Burger PC, Yu IT, Tihan T, et al. Atypical teratoid/rhabdoid tumor of the central nervous system: a highly malignant tumor of infancy and childhood frequently mistaken for medulloblastoma: a Pediatric Oncology Group study. Am J Surg Pathol 1998;22(9): 1083-1092

15 Cheng YC, Lirng JF, Chang FC, et al. Neuroradiological findings in atypical teratoid/rhabdoid tumor of the central nervous system. Acta Radiol 2005;46(1):89-96

16 Bambakidis NC, Robinson S, Cohen M, Cohen AR. Atypical teratoid/ rhabdoid tumors of the central nervous system: clinical, radiographic and pathologic features. Pediatr Neurosurg 2002;37(2):64-70

17 Yoon CS, Chuang S, Jay V. Primary malignant rhabdoid tumor of the brain: CT and MR findings. Yonsei Med J 2000;41(1):8-16

18 Hanna SL, Langston JW, Parham DM, Douglass EC. Primary malignant rhabdoid tumor of the brain: clinical, imaging, and pathologic findings. AJNR Am J Neuroradiol 1993;14(1):107-115

19 Evans A, Ganatra R, Morris SJ. Imaging features of primary malignant rhabdoid tumour of the brain. Pediatr Radiol 2001; 31(9):631-633

20 Howlett DC, King AP, Jarosz JM, et al. Imaging and pathological features of primary malignant rhabdoid tumours of the brain and spine. Neuroradiology 1997;39(10):719-723

21 Tez S, Köktener A, Güler G, Ozişik P. Atypical teratoid/rhabdoid tumors: imaging findings of two cases and review of the literature. Turk Neurosurg 2008;18(1):30-34 